\title{
Mapping and Environmental Diagnosis in Native Acai Areas in the Amazon
}

\author{
Daniele Cristina de Brito Lima Soares ${ }^{1}$, Herdjania Veras Lima ${ }^{1}$, Suzana Romeiro Araújo ${ }^{1}$, Lorena Chagas Torres ${ }^{1}$ \\ \& Antônio Clementino dos Santos ${ }^{2}$ \\ ${ }^{1}$ Universidade Federal Rural da Amazônia, Belém, Pará, Brazil \\ ${ }^{2}$ Universidade Federal Tocantins, Araguaína, Tocantins, Brazil \\ Correspondence: Daniele Cristina de Brito Lima Soares, Programa de Pós-graduação em Agronomia, \\ Universidade Federal Rural da Amazônia, Belém, Pará, Brazil. E-mail: eleinad.lima@gmail.com; \\ daniele.soares@ufra.edu.br
}

Received: February 26, 2021

Accepted: March 31, $2021 \quad$ Online Published: April 15, 2021

doi:10.5539/jas.v13n5p179

URL: https://doi.org/10.5539/jas.v13n5p179

\begin{abstract}
For several decades, the Acai orchards (acaizais) have directly influenced the survival of the families in the Amazonian floodplains. In this period, the production of the Acai fruit for local consumption was ceased and became an export item produced in intensive management, resulting in an increase in orchards in the floodplains and the emergence of dryland plantations, no longer representing a typical extractive activity in the Amazon. The objective of this study was to map the classes of use and coverage, and the occurrences of the Acai orchards massifs, as well as to analyze the physical and chemical parameters of five islands in the municipality of Igarapé-Miri, State of Pará, Brazil, where there is a great occurrence of productive Acai orchards. This work evaluated the following islands: Jarimbu, Mamangal, Itaboca, Mutirão, and Buçu, where geolocalized collections were carried out in the areas with the highest occurrence of Acai orchards, both to assist in the classification of images and for soil sampling. August 2019 Planet images were processed using the unsupervised method, where seven classes of cover use were obtained: hydrography, exposed soil, urban, alluvial, lowland, arboreal, and agriculture areas. Therefore, occurrences of productive orchards were identified and correlated to the good attributes of soil fertility in the floodplains under continuous flooding and sedimentation. The correlation confirmed the higher productivity of Acai in the Alluvial and Lowland classes, which predominate in the evaluated area, presenting soils considered fertile with a loam-clay-silty and loam -silty texture, high base saturation (greater than 50\%), high organic matter content, and significant presence of potassium and phosphorus.
\end{abstract}

Keywords: Acai, Amazon floodplains, geotechnologies, soil parameters

\section{Introduction}

Among the native cultures of the Amazon region, Acai (Euterpe oleracea Mart.) stands out as the most economic, social, and culturally important crop. This is a species that is part of the native forest, predominantly found in lowland areas (Nogueira, 1997; Tregidgo et al., 2020). The State of Pará stands out nationally as the largest Acai producer, with an annual production of 1,274,056 tons of fruit (IBGE, 2019).

The rise in the demand for Acai fruit caused a great interest in the management of Acai palms in the floodplain areas (Homma et al., 2006) and the expansion of Acai forests managed in non-flooded areas, with the use of irrigation (Farias Neto et al., 2011). These changes in the management have already been recorded, but studies in the non-flooded forest are still rare (Jardim et al., 2004; Lôbo et al., 2011; Arroyo-Rodríguez et al., 2013).

The native Acai areas had an increase in production, on the other hand, it has modified the floodplain ecosystem, also causing significant erosion on the islands (Tagore et al., 2018), causing the weakening of the slopes and, consequently, the deposition of large quantities of sediment in the riverbed due to the uncontrolled deforestation (Gonçalves \& Brasil, 2016). However, Brito et al. (2020) consider that studies of this nature, reinforce the importance of the production/conservation of native species. 
However, the Acai fruit trade is an alternative with great economic potential and that essentially contributes to the income of extractive communities in the Amazon (Silva et al., 2019) promoting the sustainable exploitation of floodplain forests (Homma et al., 2006) and expanding the local and national economies (Tagore et al., 2018).

In this context, studies on the mapping of large areas of Acai orchards in the Legal Amazon are still scarce. Not even the local community has an estimate of the size of the areas explored there, as well as their transformations and impacts over the years. In the most recent studies by Lima et al. (2018) on environmental degradation identified by coverage analysis, the use of technologies was effective for assessing the behavior of vegetation, allowing to monitor and estimate the expansion of changes in the environment. The use of digital image classification techniques provides a synoptic view and information on the temporal dimension of spatial phenomena, allowing the generation of information on the dynamics and spatial patterns of the landscape in areas of large territorial extensions (De Souza et al., 2019).

The use of high-spatial-resolution sensors, as is the case of the Planet sensor with a spatial resolution of three meters, has proven to be real sources in the evaluation of the characteristics of the mapped areas, consisting of reliable, solid, and active information in the analysis of the dynamics of land use and cover.

Knowledge of the soil quality through its physical-chemical and biological attributes is essential to assess impacted and cropped areas (Colodel et al., 2018), as well as the lowland areas of the Amazon (Fajardo et al., 2009). Therefore, knowing the spatial variability of soil attributes may assist in the management of areas of native Acai in this ecosystem with the use of geo-technologies, which supports the high-productive potential of the areas with the rich-natural fertility of the soils and productivity in the islands.

Thus, Rodríguez-Echeverry et al. (2018) recommend that such strategies for changing land use obtained with the use of geotechnologies can serve as crucial information for planning conservation strategies and also for subsidizing programs and other planning and other tools of territorial and environmental management and planning.

In this context, the objective of this work was to analyze through the unsupervised classification of images the thematic maps of representativeness of the areas with the highest occurrence of Acai by the ISODATA algorithm the five islands of the municipality of Igarapé-Miri/PA and to correlate the generated maps with results of the analysis of physical and chemical attributes of the soils of the areas.

\section{Material and Methods}

\subsection{Study Area}

The study was carried out in the municipality of Igarapé-Miri, located in the Low Tocantins region in the mesoregion in the northeastern Para State. The municipality is located $78 \mathrm{~km}$ from the capital of the state of Pará, Brazil, and has a territorial area of 199.679 ha (IBGE, 2019) (Figure 1). The climate in the region is of the tropical humid type corresponding to the megathermic type Ami according to Köppen's classification. The annual rainfall is greater than $2,000 \mathrm{~mm}$ with an average annual temperature of $27{ }^{\circ} \mathrm{C}$ and air relative humidity of $80 \%$ (Alvares et al., 2013).

Five islands participating in the Agroextractive Settlement Project (PAE) and that are also more representative for the Acai fruit were selected (Table 1). 


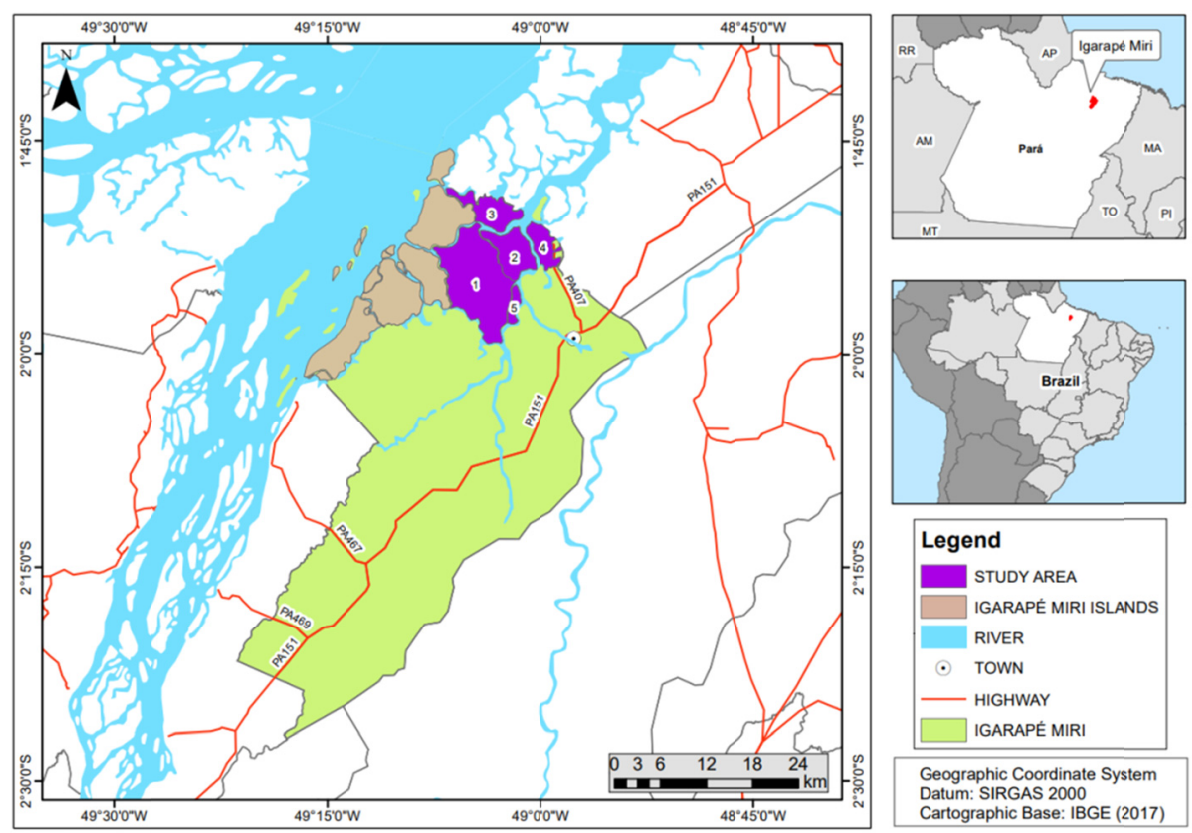

Figure 1. Study area location, islands region-Igarapé-Miri

Table 1. Characteristics of the islands in the study area

\begin{tabular}{lllll}
\hline \multirow{2}{*}{ Island } & \multicolumn{2}{c}{ Coordinates } & \multirow{2}{*}{ Altitude (m) } & \multirow{2}{*}{ Area (ha) } \\
\cline { 2 - 4 } & Latitude & Longitude & & $8,673.71$ \\
\hline JARIMBU & $1^{\circ} 54^{\prime} 27.18^{\prime \prime} \mathrm{S}$ & $49^{\circ} 4^{\prime} 17.25^{\prime \prime} \mathrm{W}$ & 6 & $2,590.76$ \\
MAMANGAL & $1^{\circ} 53^{\prime} 13.67^{\prime \prime} \mathrm{S}$ & $49^{\circ} 1^{\prime} 30.95^{\prime \prime} \mathrm{W}$ & 8 & $2,806.13$ \\
ITABOCA & $1^{\circ} 50^{\prime} 14.17^{\prime \prime} \mathrm{S}$ & $49^{\circ} 2^{\prime} 54.44^{\prime \prime} \mathrm{W}$ & 16 & $1,708.52$ \\
MUTIRÃO & $1^{\circ} 52^{\prime} 21.30^{\prime \prime} \mathrm{S}$ & $49^{\circ} 0^{\prime} 8.44^{\prime \prime} \mathrm{W}$ & 12 & 506.57 \\
BUÇU & $1^{\circ} 56^{\prime} 3.01^{\prime \prime} \mathrm{S}$ & $49^{\circ} 1^{\prime} 48.35^{\prime \prime} \mathrm{W}$ & 7 & 7 \\
\hline
\end{tabular}

\subsection{Collection and Pre-processing of Satellite Images}

Eight images of the Planet sensor obtained on August 9 and 10, 2019, were used, upon request to the State Secretariat of Environment and Sustainability of Pará (SEMAS), and then transferred to the Federal Rural University of the Amazon (UFRA) for use in research. The images have a spatial resolution of 3 meters composed of the following spectral bands: Band 1 (455-515 nm), Band 2 (500-590 nm), Band 3 (590-670 nm), and Band 4 (590-670 nm). The islands' shapefile was downloaded directly from the land collection of the National Institute for Colonization and Agrarian Reform (INCRA).

The images were georeferenced and submitted to atmospheric correction. All pre-processing of the satellite images used in the experiment was carried out individually for each island using the QGis software. The image was cut out with the delimitation of each island and, later, the mosaic was done.

\subsection{Unsupervised Image Classification}

After the image pre-processing, the unsupervised classification was developed in the ENVI 5.3 software using the ISODATA algorithm (Iterative Selforganizing Data Analysis Technique) developed by (Geoffrey \& Hall, 1965). The advantages of using this algorithm are related to not needing the knowledge of the evaluated area, the minimization of human errors as the fact that the pixels are spectrally separated and the control over the number of classes and interactions by the analyst (Morariu \& Burescu, 2018).

For the formation of a cluster and grouping, based on the Euclidean distance, the minimum spectral distance formula was used as (Swain \& Davis, 1978), according to (Equation 1):

$$
\mathrm{SD}_{\mathrm{xyc}}=\sqrt{\sum_{\mathrm{i}}^{\mathrm{n}}=1\left(\mu_{\mathrm{ci}}-\mathrm{X}_{\mathrm{xyi}}\right)^{2}}
$$


Where, $n$ : number of bands; i: band number; c: private class; $X_{x y i}$ : file value of the pixel data $x, y$ in band $i ; \mu_{\mathrm{ci}}$ : mean of the data file values (digital numbers) in $i$ for the c class sample; $\mathrm{SD}_{\mathrm{xyc}}$ : Spectral distance of pixels $\mathrm{x}, \mathrm{y}$ the $\mathrm{c}$ class mean.

The definition standard was applied to a classification with a parameter of 30 classes, allowing the software to separate the different targets from the image and with interaction parameters specified in 15 for monitoring the process.

\subsection{Satellite Image Post-Processing}

The image analysis for post-processing of the results was performed through visual interpretation. This procedure consists of interpreting the image directly on the computer screen, using basic elements, such as color, texture, shape, shade, size, shadow, pattern, adjacencies, and geographic location (Loch, 1993; Temba, 2000; Gomes, 2001; Moreira, 2003; Barcellos et al., 2005). The reclassification was performed manually, pixel by pixel using the ClassEdit complement of the no Envi software. The complete processing from image collection to the classification analysis is represented in (Figure 2).

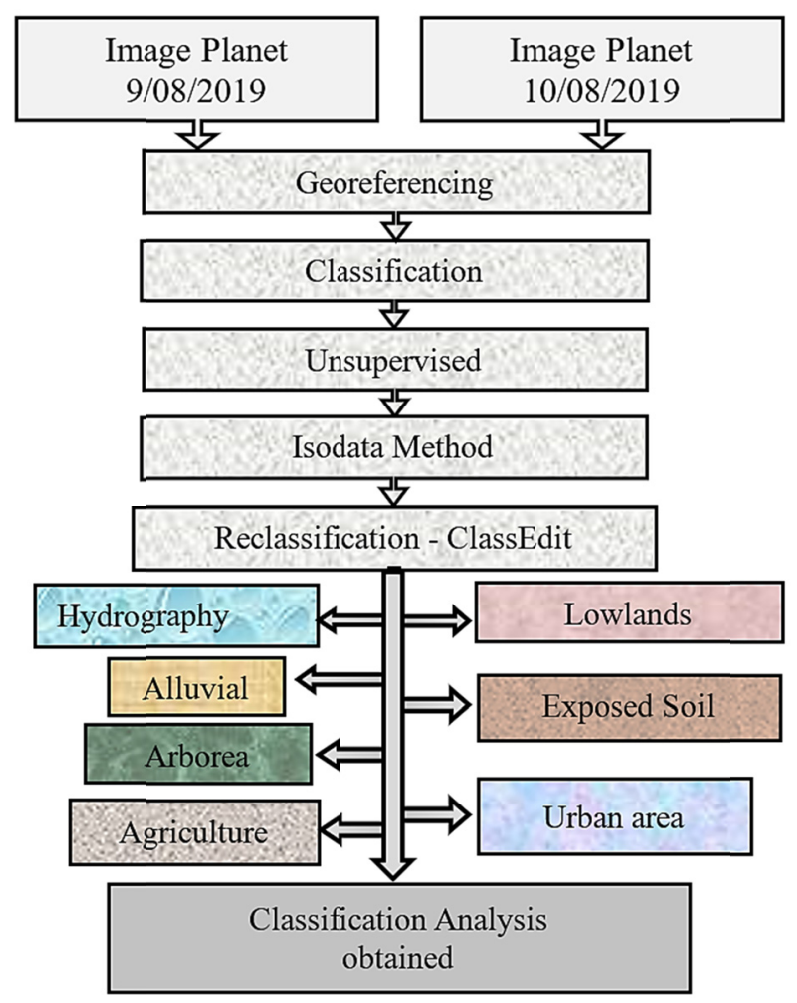

Figure 2. Flow chart of the developed methodology

The objective of the reclassification is to gather subclasses in their corresponding classes, which will promote the understanding of the classification (Matsukuma, 2002). This technique automatically separates the pixels into groups (clusters) of a similar spectral character (Verma et al., 2017), generating a highly successful analysis of the clusters (Meneses \& Almeida, 2012). For a better understanding of the classification, descriptions were generated based on the type of class generated in the study (Table 2). 
Table 2. Classification and description of land use and occupation

\begin{tabular}{|c|c|}
\hline Class type & Description \\
\hline Hydrography & Rivers, canals, holes, lakes, igarapés (Amazon streams) \\
\hline Exposed soil & Sandbank, roads, uncovered soil \\
\hline Urban areas & Houses, village, built areas \\
\hline Alluvial & Acai palm with the constant presence of water \\
\hline Lowlands & Acai palms without the presence of water \\
\hline \multirow{4}{*}{ Arborea } & Tall and dense trees: Ucuuba (Virola surinamensis), Andiroba (Carapa guianensis), Ruber tree (Hevea brasiliensis), \\
\hline & Mututi (Pterocarpus santalinoides), Munguba (Pachira aquatica), among others \\
\hline & Small and fruit trees: mango (Mangifera indica), cacao (Theobroma cacao), Buriti (Mauritia flexuosa), \\
\hline & Taperebá (Sponidas nombin) among others \\
\hline Agriculture & Monocultivation and Agroforest systems \\
\hline
\end{tabular}

For noise elimination and image smoothing, the Majority parameters $3 \times 3$ filter was applied (Vasconcelos et al., 2016). Then, the classification was edited through visual interpretation according to the spectral behavior of each pixel (Duarte \& Silva, 2019). After, the file was transformed into a vector file (shapefile) and quantified, generating tabulated data.

The following methodological actions were used to measure the classification process of Planet images:

i) Evaluation of errors of omission and commission (statistics of the percentage of errors and successes of the pixel-by-pixel classification, attributed by the Confusion matrices); ii) Post-classification visual inspection checking the distribution and connection between the generated classes, the existence of isolated pixels, and the need for classification editing; iii) Validation and in loco confirmation through the georeferenced collection in the mapped classes at visiting the study area before and after the image classification process.

\subsection{Soil Sampling}

In the areas with the highest occurrence of Acai, disturbed soil samples were collected in the 0-0.10 m layer, at a distance of 50 to $100 \mathrm{~m}$ from the river bank and 1 to $2 \mathrm{~km}$ from one collection point to another, totaling 19 samples for the five islands. Then, the samples were air-dried, ground, and passed through a 2-mm opening sieve to obtain the air-dried fine earth (ADFE). This sampling was carried out in August, a period of low rainfall in the region. All collection points were geo-referenced with the aid of GPS (Global Position System).

\subsection{Soil Laboratory Analysis}

The chemical attributes of the soil were determined according to the methodology of Teixeira et al. (2017): $\mathrm{pH}$ in water and $\mathrm{KCl}$ in the soil:solution (1:2.5) rate. Available $\mathrm{P}$ and $\mathrm{K}$, extracted by Mehlich-1 $\left(0.0125 \mathrm{~mol} \mathrm{~L}^{-1}\right.$ of $\mathrm{H}_{2} \mathrm{SO}_{4}+0.05 \mathrm{~mol} \mathrm{~L}^{-1}$ of $\mathrm{HCl}$ ), and $\mathrm{P}$ determined by colorimetry and $\mathrm{K}$ by flame photometry; $\mathrm{Al}, \mathrm{Ca}$ and $\mathrm{Mg}$ extracted with $\mathrm{KCl} 1 \mathrm{~mol} \mathrm{~L}^{-1}$; $\mathrm{Al}$ determined by titration (neutralization volume), while $\mathrm{Ca}$ and $\mathrm{Mg}$ were determined by complexometry with EDTA; $\mathrm{H}+\mathrm{Al}$ extracted with $1 \mathrm{~mol} \mathrm{~L}^{-1}$ calcium acetate solution at $\mathrm{pH} 7.0$ and determined by titration. Organic carbon was determined by the modified method of (Walkley \& Black, 1934), based on the principle of oxidation of organic matter, with potassium dichromate in the sulfuric medium.

The particle size distribution was determined using the pipette method using $1 \mathrm{M} \mathrm{NaOH}$. Before dispersion, samples with an organic matter content $>5 \%$ were pre-treated to remove organic matter with $\mathrm{H}_{2} \mathrm{O}_{2}($ Gee \& Bauder, 1986). The sand fraction was separated through sieving, the clay by sedimentation, and the silt fraction calculated by the difference.

\section{Results and Discussion}

\subsection{Land Use and Soil Cover Classification on the Islands}

The results obtained for the unsupervised reclassification of land use and the cover of the five islands using the IsoData method generated the identification of ash level patterns. These patterns are defined as samples grouped by clusters of space units (Olofsson et al., 2014).

It was observed the generation of a new classification by grouping applied in the Planet 2019 Images (Figure 3). The images were selected exactly during the Acai harvest period, which provided a good spatial resolution of the areas and, consequently, allowed the identification of the Acai massifs on each island and the most relevant classes. 


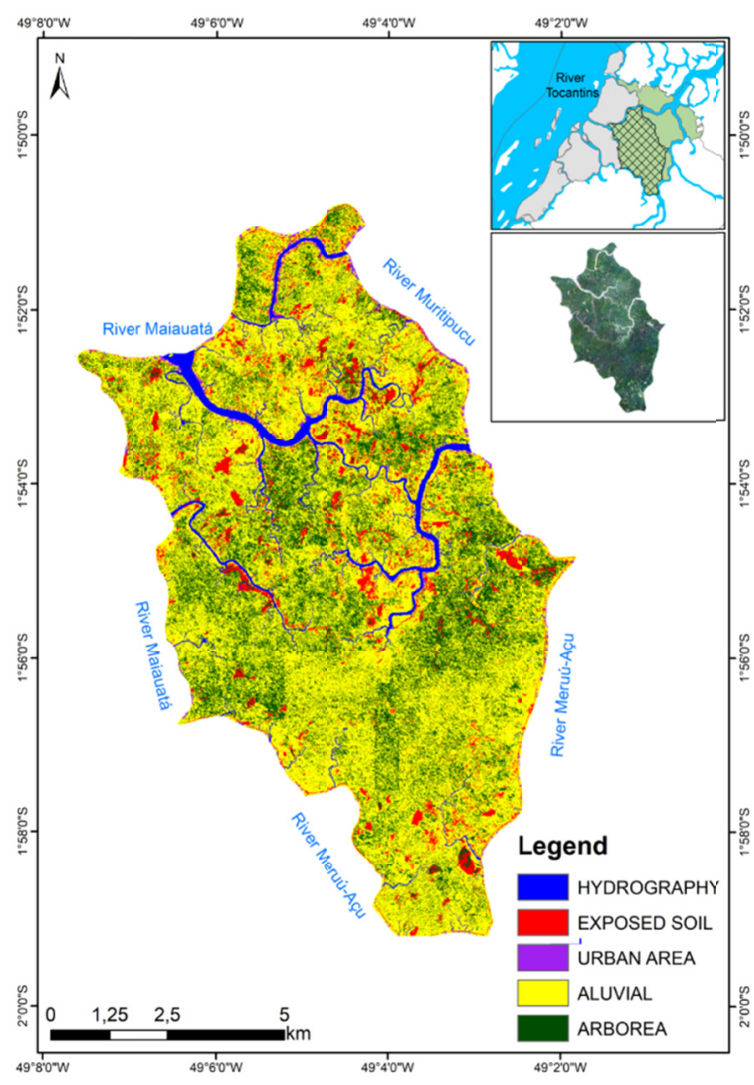

(A)

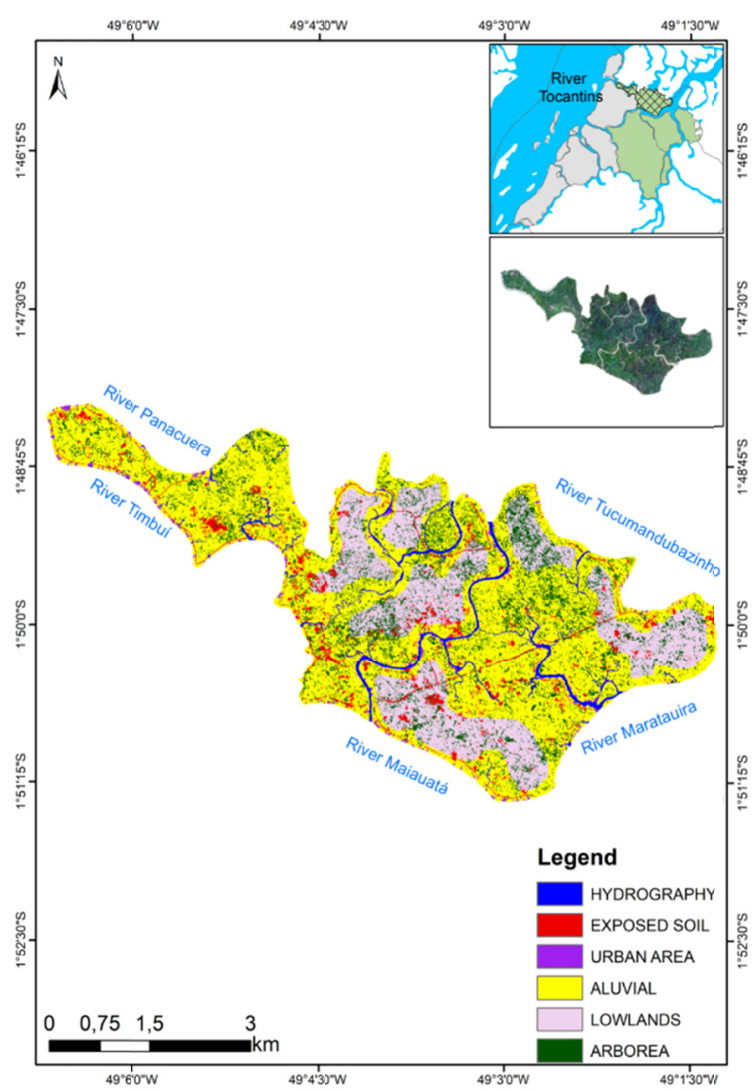

(C)

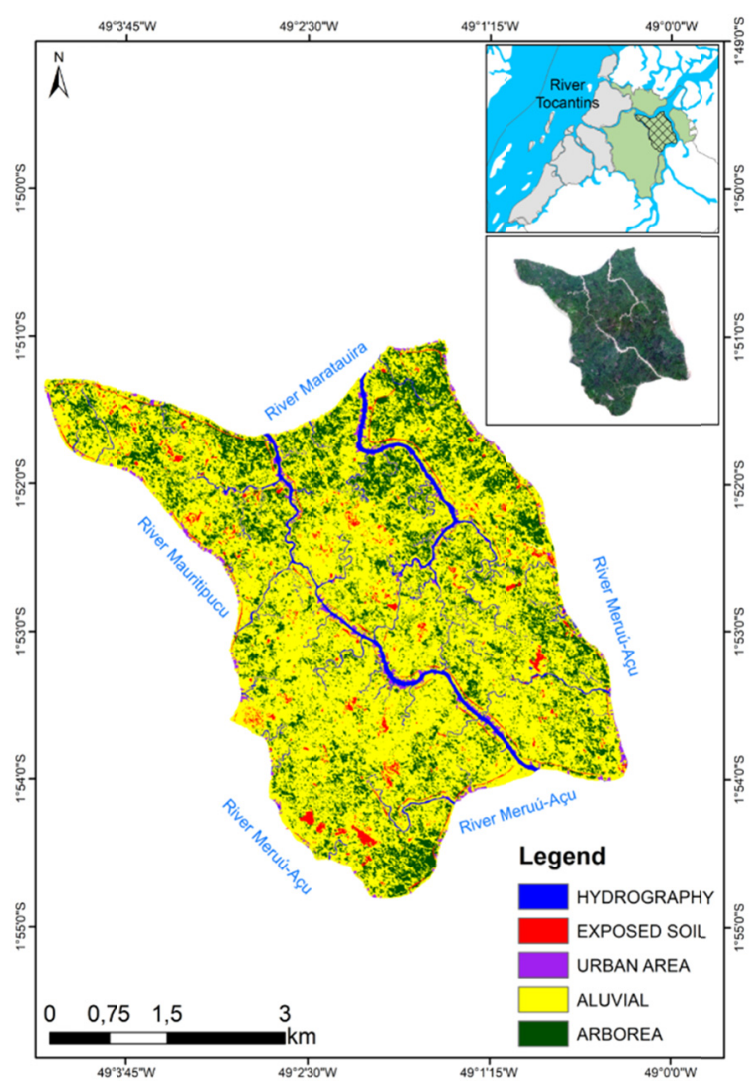

(B)

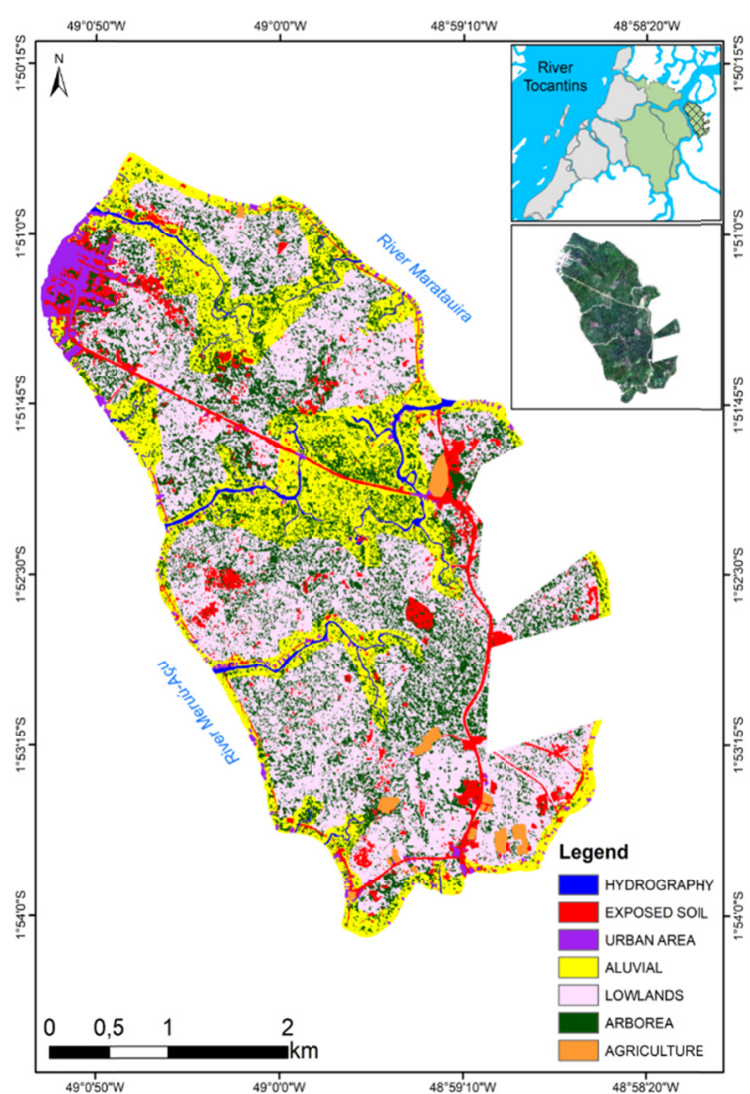

(D) 


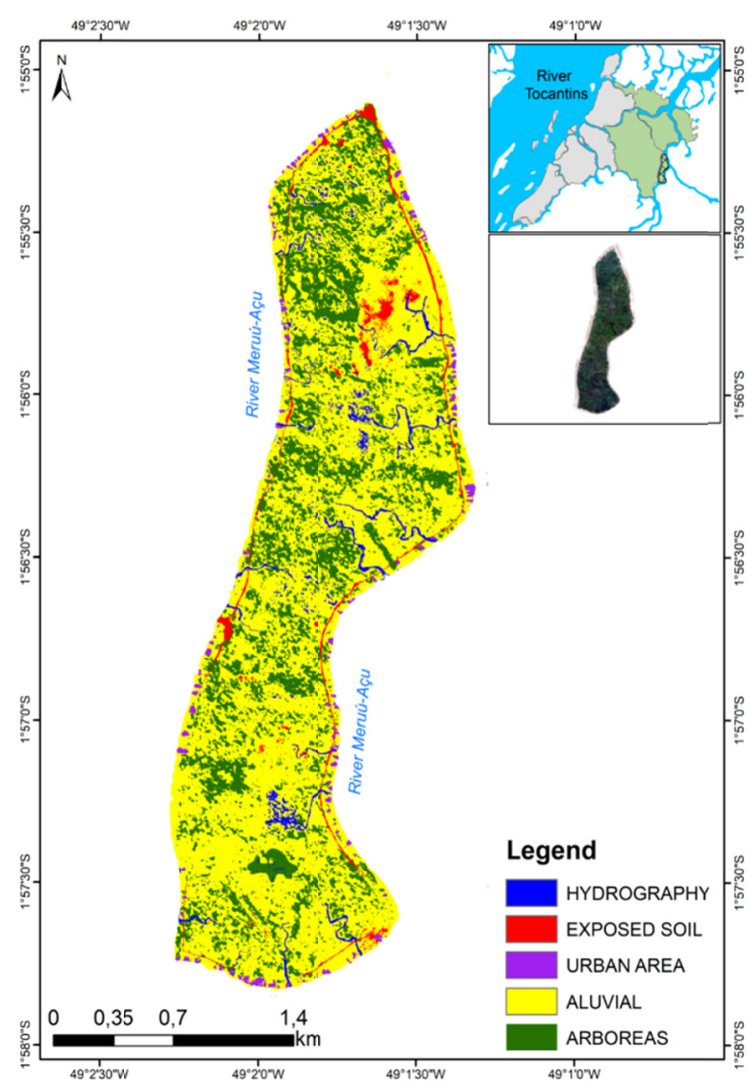

(E)

Figure 3. Classification of the five areas using the unsupervised methods using Isodata algorithm

(A: Pae Jarimbu; B: Pae Mamangal; C: Pae Itaboca; D: Pae Mutirão; E: Pae Buçu)

The Alluvial and Lowland classes were observed in all the islands and, together, they represented $67.72 \%$ of the total evaluated area, i.e., 10 thousand hectares where the Acai is found (Figure 3). Homma (2014) estimated that roughly 80 thousand hectares of floodplain were transformed into homogeneous Acai areas. On the Jarimbu, Mamangal, and Buçu islands, five classes of interest were identified; Itaboca presented six classes and Mutirão seven classes, as shown in (Table 3). The characterization of the dense Ombrophilous Forest formations has two different formations: The Dense Ombrophilous Forest of the Lowlands and the Alluvial Dense Ombrophilous Forest (Veloso et al., 1991), the latter being a formation with many palms (IBGE, 2012), typical of these lowland areas in this region. For each island analyzed with its respective class raised, the values were obtained in the number of pixels and converted to the area, in hectares (Table 3).

Table 3. Representation of the classification of the areas per hectare of the five islands

\begin{tabular}{llllll}
\hline \multirow{2}{*}{ Classes } & \multicolumn{5}{c}{ PAE-ISLANDS (ha) } \\
\cline { 2 - 6 } & Jarimbu & Mamangal & Itaboca & Mutirão & Buçu \\
\hline Hydrography & 364.48 & 105.30 & 96.37 & 27.26 & 13.22 \\
Exposed soil & 645.50 & 71.54 & 143.05 & 123.84 & 11.31 \\
Urban area & 80.14 & 33.18 & 29.48 & 39.75 & 7.94 \\
Alluvial & 5529.29 & 1823.05 & 1508.43 & 320.00 & 350.53 \\
Lowlands & - & - & 611.81 & 601.83 & - \\
Arborea & 2054.30 & 557.68 & 417.00 & 413.89 & 123.57 \\
Agriculture & - & - & - & 16.95 & - \\
Total area (ha) & $8,673.71$ & $2,590.76$ & $2,806.13$ & $1,543.52$ & 506.57 \\
\hline
\end{tabular}


The percentage regarding the types of land use and occupation found for each island are shown in (Figure 4). The Lowland class was observed in only two islands, Itaboca and Mutirão, with $21.80 \%$ and $38.99 \%$ of the total area, respectively (Figure 4) due to the higher average altitudes of these areas (16 m and $12 \mathrm{~m}$, respectively) compared to the others (Table 1). In the other evaluated islands, such as Jarimbu, Mamangal, Itaboca, and Buçu, the Alluvial class represents, more than $50 \%$ of all land occupation, which demonstrates the great presence of Acai in these areas, being directly linked to networks of rivers that involve these areas.

The Mutirão island showed only $20.73 \%$ for the Alluvial class (Figure 4), which may be associated with its distribution in other classes such as lowlands, farming, urban area, and the island with the smallest network of rivers has also been confirmed by the classification of hydrography in $1.77 \%$ and, consequently for being the island that suffers the most influence by human action in the use and cover of the soil. According to Assis (2011), it is very difficult to distinguish the alluvial and lowland formations due to the physiognomic similarity between them, with great difficulty in establishing the limits between alluvial sedimentation (which constitutes the alluvial plain) and the other types of sedimentation and geomorphological features.

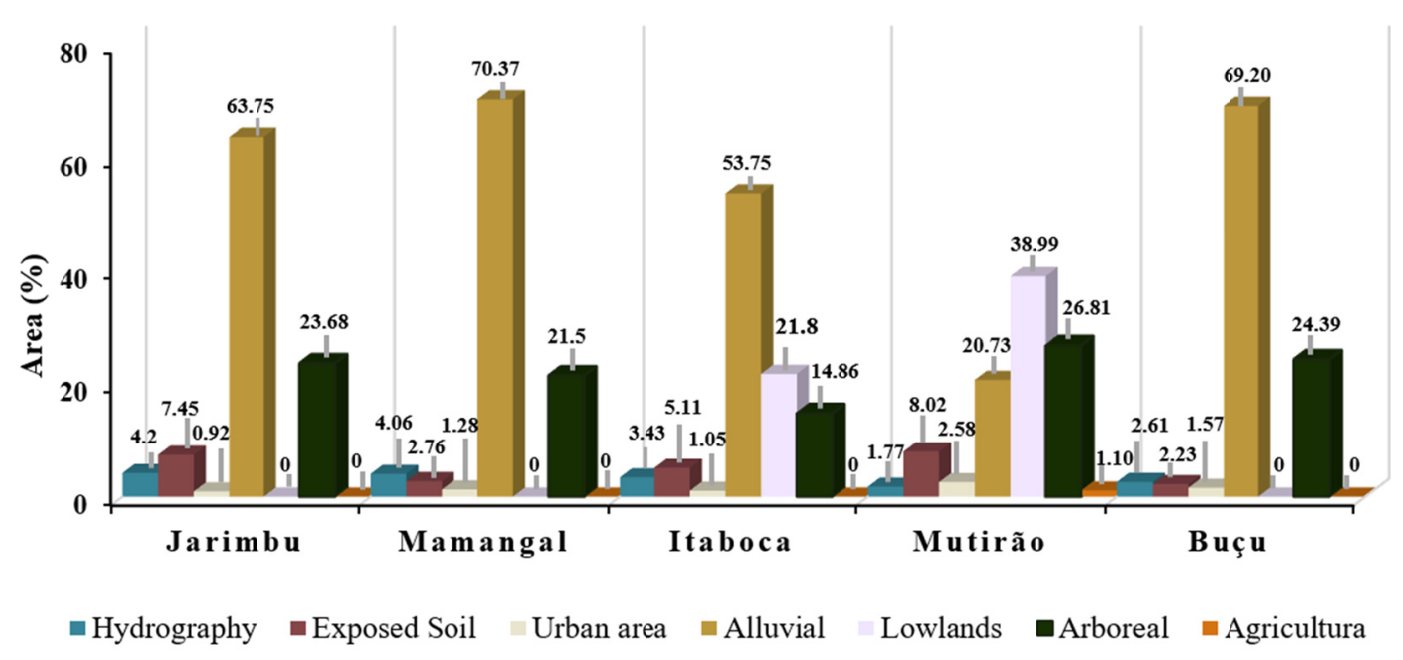

Figure 4. Percentage distribution of land use and occupation classes on Igarapé-Miri islands

The Arboreal class comprises an average value of $22 \%$ for all the evaluated islands, except for Itaboca island. Due to its distribution into classes such as Alluvial with 53.75\% and Lowlands with 21.8\% (Figure 4). According to these results, the arboreal class is the consequence of the anthropic activities carried out in the forest, such as intensive management of Acai. The rise in in the demand for the Acai fruit resulted in inadequate removal of the trees resulting in more than $50 \%$ loss of tree species diversity and a $63 \%$ reduction in the number of pioneer species (Freitas et al., 2015a).

The alteration in the landscape in the dense alluvial rain forest, resulting from the management of the Acai palms, was also reported by Braga and Jardim (2019). Low diversity is associated with restrictive environmental conditions, such as soil water saturation, which leads to the formation of a non-uniform community, with the dominance of a few species, known as oligo-species (few species with large numbers of individuals) (Almeida et al., 2004; Carvalho et al., 2009). However, this has been being accelerated by anthropic practices. Santos Júnior et al. (2015) reports that the reduction in the floodplain biodiversity has been disfavoring other species, corroborating with studies by Tregidgo et al. (2020) in the selective removal of other tree species.

Regarding the Exposed Soil class, the Mutirão, Jarimbu, and Itaboca islands stood out with values of 8.02\%, $7.45 \%$, and $5.11 \%$, respectively. This proportion is attributed to areas of farming, roads, soil cleaning, and sandbanks. Braga and Jardim (2019), in their studies of Alluvial Dense Rainforest in Pará, also conclude that these areas are possibly cleared using thinning which promoted the development of the palm and inhibited the regeneration mechanisms, chasing away the dispersing fauna and opening clearings. Because it is a class that exposes the islands' soils, it becomes a negative point as native species were removed, leading to the erosion of these soils. 
As for the Agriculture class, only one island displayed this characteristic, the Mutirão island with 16.95 (ha) in its extension, representing $1.1 \%$, as this is located closer to the margin of the municipality of Igarapé-Miri and acts as Acai Road, an important highway which is the outlet for all fruit production from the adjacent islands.

Farming carried out by riverside dwellers occurs through clearing and thinning processes in their areas, as a way of implementing some crops, as reported by Silva et al. (2018) in their studies which show that of the 130 settlers on Island Mamangal, 28\% have agroforestry systems (AFSs) in their areas, explained mostly by diversification (production), family food and shading of the Acai (Euterpe oleracea Mart.) crop. This reality coincides with what occurs on the other islands, as these are practices found by the riverside people to implement the AFSs as a form of income for these families.

The Urban Area class characterized in this study is represented by houses, villages, and built areas (Table 2). Mutirão Island is the most representative in this class, with $2.58 \%$ of the total area. On the Other hand, Jarimbu, Mamangal, Itaboca, and Buçu islands present, respectively, $0.92 \%, 1.28 \%, 1.05 \%$, and $1.57 \%$ of the urban area (Figure 4). It was observed that the urban area in all islands is predominantly on the banks of rivers. In general, traditional populations in the Amazon maintain a strong connection with the river network, since they provide connectivity and mobility for their populations (Amaral et al., 2013).

The class characterized as Hydrography is found on all islands. Canto (2007) reports that the floodplains are large strips that border the rivers and are periodically covered by water. However, Tagore et al. (2018) point out that river courses have been being altered by the flow of the vessels, increasing the width of channels. It is worth mentioning that only the internal areas of each island were classified as Hydrography, therefore its outer edge in the image was not classified as in (Figure 3), which allowed to observe and determine the amount of water within each island.

\subsection{Classification of the Island Soil}

The results of soil chemical attributes are shown in (Table 4). The soils on the islands Mamangal, Itaboca, and Mutirão had the lowest mean $\mathrm{pH}$ values in water and $\mathrm{KCl}$, in relation to the soil of the islands Jarimbu and Buçu. The more acidic $\mathrm{pH}$ in the soils of the islands of Mamangal, Itaboca, and Mutirão is the outcome of the ferrolysis process, which is common in soils subject to hydromorphism and rich in iron (Van Breemen \& Buurman, 2002).

A work of soil genesis with flooding cycles has shown that high acidity has been observed in superficial horizons in lowland soils due to ferrolysis (Barbiero et al., 2010; Coringa et al., 2012; Da Silva et al., 2019). Studies in Gleisoil under native vegetation on the banks of the Guamá River attested acid $\mathrm{pH}$ in water and $\mathrm{KCl}$ associated with the alternation between flood and ebb tide (Lopes et al., 2006).

The nutrient content in the evaluated soils showed wide distribution and high variation within each area, with base saturation $>50 \%$ in the topsoil and also higher values of organic carbon (OC) and $(\mathrm{pH})$ for the Jarimbu and Buçu islands. Freitas et al., (2015 b) in a floodplain study, reports that high values of base saturation and $\mathrm{pH}$ are widely used in the indication of soil fertility. While for the other three islands, Mamangal, Itaboca, and Mutirão, base saturation was $<50 \%$ and $\mathrm{OC}$ with lower values. 
Table 4. Descriptive statistics of the soil chemical properties on native Acai palm plantation located in five municipalities in the state of Pará $(\mathrm{n}=19)$. Depth: 0-0.10 m

\begin{tabular}{|c|c|c|c|c|c|c|c|c|c|c|c|c|}
\hline & $\mathrm{pH}$ & & $\mathrm{OC}$ & $\mathrm{P}$ & $\mathrm{K}$ & $\mathrm{Ca}$ & $\mathrm{Mg}$ & $\mathrm{Al}$ & $\mathrm{H}+\mathrm{Al}$ & SB & $\mathrm{CEC}$ & $\mathrm{V}$ \\
\hline & $\mathrm{H}_{2} \mathrm{O}$ & $\mathrm{KCl}$ & $\mathrm{g} \mathrm{kg}^{-1}$ & $\mathrm{mg} \mathrm{dm}^{-3}$ & ------ & --------- & -ב---- & $\mathrm{mol}_{\mathrm{c}} \mathrm{dm}$ & 3 & - & -------- & $\%$ \\
\hline \multicolumn{13}{|c|}{$S_{\text {JAR }}($ Jarimbu Island) } \\
\hline Min. & 5.48 & 4.37 & 45.06 & 12.97 & 0.40 & 4.48 & 1.04 & 0.12 & 1.65 & 5.92 & 7.56 & 78.23 \\
\hline Max. & 7.96 & 7.10 & 149.81 & 263.71 & 0.54 & 13.15 & 1.89 & 0.47 & 16.67 & 15.58 & 32.25 & 48.32 \\
\hline Mean & 6.28 & 5.42 & 102.48 & 90.61 & 0.47 & 8.38 & 1.31 & 0.23 & 9.75 & 10.16 & 19.91 & 51.02 \\
\hline SD & 1.13 & 1.18 & 43.16 & 118.74 & 0.08 & 3.57 & 0.39 & 0.16 & 6.18 & 4.05 & 10.23 & 39.56 \\
\hline $\mathrm{CV}(\%)$ & 18.03 & 21.73 & 42.12 & 131.04 & 16.92 & 42.64 & 30.22 & 72.93 & 63.42 & 89.79 & 153.21 & 58.61 \\
\hline \multicolumn{13}{|c|}{$S_{M A M}($ Mamangal Island) } \\
\hline Min. & 5.58 & 4.76 & 24.65 & 5.16 & 0.32 & 5.09 & 1.47 & 0.12 & 8.31 & 6.88 & 15.19 & 45.28 \\
\hline Max. & 5.92 & 5.00 & 38.54 & 13.67 & 0.47 & 7.68 & 3.49 & 0.27 & 11.52 & 11.64 & 23.16 & 50.26 \\
\hline Mean & 5.74 & 4.88 & 31.93 & 9.03 & 0.39 & 5.77 & 2.21 & 0.20 & 9.90 & 8.37 & 18.27 & 45.82 \\
\hline SD & 0.14 & 0.13 & 5.90 & 3.99 & 0.07 & 1.28 & 0.89 & 0.06 & 1.31 & 2.24 & 3.55 & 63.05 \\
\hline CV (\%) & 2.46 & 2.61 & 18.48 & 44.22 & 18.02 & 22.13 & 40.32 & 32.66 & 13.26 & 80.47 & 93.73 & 85.85 \\
\hline \multicolumn{13}{|c|}{$S_{I T A}($ Itaboca Island) } \\
\hline Min. & 5.77 & 4.54 & 22.11 & 7.83 & 0.32 & 4.91 & 1.63 & 0.20 & 8.52 & 6.85 & 15.37 & 44.57 \\
\hline Max. & 6.17 & 5.18 & 44.46 & 20.16 & 0.53 & 7.71 & 2.00 & 0.24 & 10.04 & 10.24 & 20.28 & 50.49 \\
\hline Mean & 5.93 & 4.95 & 34.01 & 16.26 & 0.43 & 6.27 & 1.77 & 0.21 & 9.21 & 8.47 & 17.67 & 47.90 \\
\hline $\mathrm{SD}$ & 0.19 & 0.28 & 9.18 & 5.67 & 0.09 & 1.16 & 0.16 & 0.02 & 0.71 & 1.42 & 2.13 & 66.59 \\
\hline CV (\%) & 3.16 & 5.62 & 26.99 & 34.90 & 22.26 & 18.55 & 9.06 & 9.52 & 7.73 & 49.87 & 57.60 & 86.58 \\
\hline \multicolumn{13}{|c|}{$S_{M U T}$ (Mutirão Island) } \\
\hline Min. & 5.49 & 4.72 & 28.88 & 6.79 & 0.39 & 5.92 & 1.65 & 0.12 & 11.60 & 7.97 & 19.57 & 40.71 \\
\hline Max. & 5.97 & 5.24 & 86.50 & 240.87 & 0.50 & 11.12 & 2.85 & 0.24 & 13.99 & 14.47 & 28.46 & 50.85 \\
\hline Mean & 5.81 & 5.04 & 51.74 & 69.20 & 0.44 & 7.89 & 2.38 & 0.19 & 12.73 & 10.71 & 23.43 & 45.69 \\
\hline SD & 0.22 & 0.24 & 25.87 & 114.51 & 0.04 & 2.27 & 0.53 & 0.05 & 1.00 & 2.84 & 3.84 & 73.93 \\
\hline CV (\%) & 3.73 & 4.73 & 50.00 & 165.48 & 10.07 & 28.77 & 22.17 & 26.49 & 7.87 & 61.02 & 68.89 & 88.57 \\
\hline \multicolumn{13}{|c|}{$S_{B U}($ Buçu Island) } \\
\hline Min. & 5.59 & 4.98 & 40.23 & 9.52 & 0.35 & 6.96 & 0.67 & 0.12 & 2.55 & 7.97 & 10.52 & 75.76 \\
\hline Max. & 7.79 & 6.77 & 97.37 & 198.15 & 0.52 & 8.56 & 2.72 & 0.24 & 13.62 & 11.80 & 25.42 & 46.43 \\
\hline Mean & 6.42 & 5.61 & 61.33 & 86.27 & 0.41 & 7.53 & 1.98 & 0.20 & 9.51 & 9.92 & 19.43 & 51.07 \\
\hline SD & 1.20 & 1.00 & 31.36 & 99.10 & 0.10 & 0.89 & 1.14 & 0.07 & 6.06 & 2.14 & 8.19 & 26.07 \\
\hline CV (\%) & 18.64 & 17.80 & 51.14 & 114.86 & 24.18 & 11.88 & 57.62 & 34.64 & 63.71 & 93.68 & 157.39 & 59.52 \\
\hline
\end{tabular}

Note. OC: organic carbon; $\mathrm{H}+\mathrm{Al}$ : potential acidity; SB: sum of bases; CEC: cation exchange capacity; V\%: base saturation; $\mathrm{SD}$ : standard deviation; $\mathrm{CV}$ : variation coefficient.

The sum of bases highly contributed to the five soils, which showed high concentrations of $\mathrm{Ca}^{2+}$, where the highest mean value was shown in Jarimbu island., $8.38 \mathrm{cmol}_{\mathrm{c}} \mathrm{dm}^{-3}$, which is the island with a high concentration of (OC), therefore corroborating with studies of Neto et al. (2018) indicating that in secondary forests, the natural dynamics promotes the incorporation and maintenance of organic matter in the soil (Delarmelinda et al., 2017) concentrating high fertilization in native areas.

The OC with a highly considerable value for Jarimbu island of $102.48 \mathrm{~g} \mathrm{~kg}^{-1}$ is justified because on the margin of this there are many sawmills where all the tailings are discharged directly into the waters, and with the movement of flood and ebb from the river, these sediments are deposited, resulting in high values of organic matter in the soil, which was also found by Freitas et al. (2015b) reporting that large scale deposition of fresh organic material on the soil surface periodically without time for humification, explains the highest concentration of organic carbon in the first layer.

The highest average concentrations of $\mathrm{Mg}^{2+}$ were for the soils on the islands Mamangal and Mutirão (2.21 and $2.38 \mathrm{cmol}_{\mathrm{c}} \mathrm{dm}^{-3}$ ), respectively, and the lowest concentration value was found for the soils of the islands Jarimbu, Itaboca, and Buçu, $1.31 \mathrm{cmol}_{\mathrm{c}} \mathrm{dm}^{-3} ; 1.77 \mathrm{cmol}_{\mathrm{c}} \mathrm{dm}^{-3}$ and $1.98 \mathrm{cmol}_{\mathrm{c}} \mathrm{dm}^{-3}$, respectively; the contents of $\mathrm{K}^{+} ; \mathrm{Al}^{+}$ showed a small dispersion in the five soils in relation to the other chemical variables, showing a lower $\mathrm{K}^{+}$value $\left(0.39 \mathrm{cmol}_{\mathrm{c}} \mathrm{dm}^{-3}\right)$ for Mamangal island and lower $\mathrm{Al}^{+}$value for Mutirão island $\left(0.19 \mathrm{cmol}_{\mathrm{c}} \mathrm{dm}^{-3}\right)$ and higher mean values of $\mathrm{K}^{+}$and $\mathrm{Al}^{+}\left(0.47\right.$ and $\left.0.23 \mathrm{cmol}_{\mathrm{c}} \mathrm{dm}^{-3}\right)$ only on the Jarimbu island. 
$\mathrm{K}^{+}$is found in large amounts in plant tissues with energetic functions, and water absorption by cells (Forster et al., 2019), where all the evaluated elements favored good spatialization of the Acai palm areas in these islands, presenting higher alluvial classes in this study.

The high P concentration in the soils on the Jarimbu islands, $90.61 \mathrm{mg} \mathrm{dm}^{-3}$; Mutirão, $69.20 \mathrm{mg} \mathrm{dm}^{-3}$, and Buçu $86.27 \mathrm{mg} \mathrm{dm}^{-3}$, has a great contribution on organic matter, Where $\mathrm{P}$ is a fundamental element for the initial development of Acai plant, promoting a greater increase in the aerial part and biomass when in high availability (Araújo et al., 2018).

The cation exchange capacity and the potential acidity had a high contribution to the exchange complex in all five soils. Salviano et al. (1998) also report the similarities between CEC and potential acidity $(\mathrm{H}+\mathrm{Al})$ and how much they exert direct influence on the CEC calculation. This was also found by Freitas et al. (2015b), in which high values reflect the natural conditions of this soil and have a high capacity to retain cations.

The soils on Jarimbu, Mamangal, Itaboca, and Mutirão islands presented a silty clay-loam textural class. The soils of Buçu Island, on the other hand, presented a silt-loam textural class. However, in the soil of Jarimbu island., sand contributed more, $135.74 \mathrm{~g} \mathrm{~kg}^{-1}$ in comparison to the other islands, while the soil of Itaboca island, presented a lower proportion of silt/clay, $1.91 \mathrm{~g} \mathrm{~kg}^{-1}$ (Table 5).

Table 5. Texture classification of soils under native Acai palm in five islands in the municipality in Pará State (n =19). Depth: 0-0.10 m

\begin{tabular}{|c|c|c|c|c|c|}
\hline Areas & Sand & Clay & Silt & Silt/Clay & Texture class \\
\hline & \multicolumn{5}{|c|}{ - } \\
\hline $\mathrm{S}_{\mathrm{JAR}}$-Jarimbu Island & 135.74 & 238.44 & 625.83 & 2.62 & Silty clay-loam \\
\hline $\mathrm{S}_{\mathrm{MAM}}$-Mamangal Island & 36.59 & 306.00 & 657.41 & 2.15 & Silty-clay-loam \\
\hline $\mathrm{S}_{\text {ITA-Itaboca Island }}$ & 49.73 & 326.40 & 623.88 & 1.91 & Silty-clay-loam \\
\hline $\mathrm{S}_{\mathrm{MUT}}$-Mutirão Island & 94.29 & 285.60 & 620.11 & 2.17 & Silty-clay-loam \\
\hline $\mathrm{S}_{\mathrm{BU}}$-Buçu Island & 74.22 & 301.84 & 623.94 & 2.07 & Silty-loam \\
\hline
\end{tabular}

Although studies for floodplain soils in the islands in the Low Tocantins region are scarce and incipient (Lopes et al., 2019), the results of this experiment are relevant, as all the five soils showed similar characteristics. According to Guedes et al. (2018), they are fertile soils with fragile peculiarities, in which the soil texture particles under flood are sedimented in the lowest part of the landscape, which induces changes in texture, culminating in siltier soils (Wang et al., 2017).

\section{Conclusions}

Based on the results of this experiment, we concluded that in the areas of the Igarapé-Miri islands, large Acai orchards massifs were consolidated, expanded through favorable soil fertility conditions and efficient management practices in the floodplain areas. The zoning and spatial distribution of Acai orchards in the five studied islands (Jarimbu, Mamangal, Itaboca, Mutirão, and Buçu) through the processing and use of image classification algorithms, allowed the correlation of the mappings carried out with the major physical-chemical attributes of the soils.

The mapping established seven classes of use and cover (Hydrography, Exposed Soil, Urban Area, Alluvial, Lowlands, Arboreal, and Agriculture) where it was identified occurrences of productive orchards, correlated to the soil fertility attributes naturally imposed under flooding and sedimentation in the lowest parts in the floodplains. This correlation confirmed the indications of higher productivity of the Acai fruit in the Alluvial and Lowland classes. In these classes of greater predominance in the studied area, the soils are considered fertile and presented similar physical-chemical characteristics with a loam-clay-silty and loam-silty texture, high base saturation (greater than 50\%), high levels of organic matter, and significant presence of potassium and phosphorus.

The local community started to combine efficient management practices with environmental sustainability, with positive socio-environmental and cultural returns, resulting in promoting employment and income in the periods of Acai harvest (July to December) and off-season (January to July), supported by other local economic activities (fishing and other family farming activities). 


\section{Acknowledgements}

To the Post-Graduate Program in Agronomy at UFRA-PGAgro; Laboratory of Geoprocessing, Spatial Analysis and Satellite Monitoring-LAGAM-UFRA, EMBRAPA-Pa and the Riverside Communities of Low Tocantins.

\section{References}

Almeida, S. S., Amaral, D. D., \& Silva, A. S. L. (2004). Análise florística e estrutura de florestas de várzea no estuário amazônico. Acta Amazônica, 34(4), 513-524. https://doi.org/10.1590/S0044-59672004000400005

Alvares, C. A., Stape, J. L., Sentelhas, P. C., Moraes, G., Leonardo, J., \& Sparovek, G. (2013). Köppen's climate classification map for Brazil. Meteorologische Zeitschrift, 22(6), 711-728. https://doi.org/10.1127/09412948/2013/0507

Amaral, S., Dal'asta, A. P., Brigatti, N., Pinho, C. M. D. D., Medeiros, L. C. D. C., Andrade, P. R. D., ... Monteiro, A. M. V. (2013). Comunidades ribeirinhas como forma socioespacial de expressão urbana na Amazônia: uma tipologia para a região do Baixo Tapajós (Pará-Brasil). Revista Brasileira de Estudos de População, 30(2), 367-399. https://doi.org/10.1590/S0102-30982013000200003

Araújo, C. S., Rufino, C. P. B., Bezerra, J. L. S., Andrade Neto, R. De C., \& Lunz, A. M. P. (2018). Crescimento de mudas de açaizeiro (Euterpe oleracea Mart) Submetidas a diferentes doses de fósforo. South American Journal of Basic Education, Technical and Technological, 5(1).

Arroyo-Rodríguez, V., Rös, M., Escobar, F., Melo, F. P. L., Santos, B. A., Tabarelli, M., \& Chazdon, R. (2013). Plant b-diversity in fragmented rain forests: Testing floristic homogenization and differentiation hypotheses. J. Ecol., 101, 1449-1458. https://doi.org/10.1111/1365-2745.12153

Assis, M. A., Prata, E. M. B., Pedroni, F., Eisenlohr, P. V., Martins, F. R., Santos, F. A. M. D., \& Martins, S. C. (2011). Florestas de restinga e de terras baixas na planície costeira do sudeste do Brasil: Vegetação e heterogeneidade ambiental. Biota Neotropica, 11(2), 103-121. https://doi.org/10.1590/S1676-060320110 00200012

Barbiero, L., Kumar, M. M., Violette, A., Oliva, P., Braun, J. J., Kumar, C., \& Valles, V. (2010). Ferrolysis induced soil transformation by natural drainage in Vertisols of sub-humid South India. Geoderma, 156(3-4), 173-188. https://doi.org/10.1016/j.geoderma.2010.02.014

Barcellos, C., Pustai, A. K., Weber, M. A., \& Brito, M. R. V. (2005). Identificação de locais com potencial de transmissão de dengue em Porto Alegre através de técnicas de geoprocessamento. Revista da Sociedade Brasileira de Medicina Tropical, 38(3), 246-250. https://doi.org/10.1590/S0037-86822005000300008

Braga, E. O., \& Jardim, M. A. G. (2019). Floristica, estrutura e formas de vida do estrato inferior de uma Floresta Ombrofila Densa Aluvial, Para, Brasil/Floristic, structure and life forms of lower stratum in a Alluvial Dense Rain Forest, Para state, Brazil. Ciência Florestal, 29(3), 1048-1060. https://doi.org/ $10.5902 / 1980509821834$

Brito, A. D., Coelho, R. De F. R., \& Rosal, F. L. (2020). Os extrativistas de andiroba em projetos de assentamentos agroextrativistas (paex) da várzea de Igarapé-Miri, Pará, Brasil. Revista Agroecossistemas, 11(2), 82-101. https://doi.org/10.18542/ragros.v11i2.7303

Canto, O. D. (2007). Várzea e Varzeiro da Amazônia. Belém: MPEG.

Carvalho, J., Marques, M. C. M., Roderjan, C. V., Barddal, M., \& de Sousa, S. G. A. (2009). Relações entre a distribuição das espécies de diferentes estratos e as características do solo de uma floresta aluvial no Estado do Paraná, Brasil. Acta Botanica Brasilica, 23(1), 1-9. https://doi.org/10.1590/S0102-33062009000100002

Colodel, J. R., Pierangeli, M. A. P., Souza, M. F. P., Carvalho, M. A. C. D., \& Dalchiavon, F. C. (2018). Atributos físicos e biológicos de Argissolo Vermelho-Amarelo Amazónico sob diferentes sistemas de uso e manejo. Revista de Ciências Agrárias, 41(2), 1-10. https://doi.org/10.19084/RCA17253

Coringa, E. D. A. O., Couto, E. G., Otero Perez, X. L., \& Torrado, P. V. (2012). Atributos de solos hidromórficos no Pantanal Norte Matogrossense. Acta Amazonica, 42(1), 19-28. https://doi.org/10.1590/S0044-59672 012000100003

Da Silva, L. F., Fruett, T., Zinn, Y. L., Inda, A. V., \& Do Nascimento, P. C. (2018). Genesis, morphology and mineralogy of Planosols developed from different parent materials in southern Brazil. Geoderma, 341, 46-58. https://doi.org/10.1016/j.geoderma..12.010 
De Souza, A. R., Escada, M. I. S., Marujo, R. D. F. B., \& Monteiro, A. M. V. (2019). Cartografia do Invisível: Revelando a Agricultura de Pequena Escala com Imagens Rapideye na Região do Baixo Tocantins, PA. Revista Do Departamento De Geografia, 38, 137-153. https://doi.org/10.11606/rdg.v38i1.151603

Delarmelinda, E. A., De Souza Júnior, V. S., Wadt, P. G. S., Deng, Y., Campos, M. C. C., \& Câmara, E. R. G. (2017). Soil-landscape relationship in a chronosequence of the middle Madeira River in southwestern Amazon, Brazil. Catena, 149, 199-208. https://doi.org/10.1016/j.catena.2016.09.021

Duarte, M. L., \& Da Silva, T. (2019). Avaliação do desempenho de três algoritmos na classificação de uso do solo a partir de geotecnologias gratuitas. Revista de Estudos Ambientais, 21(1), 6-16. https://doi.org/ 10.7867/1983-1501.2019v21n1p6-16

E Silva, J. I. D. S., Junior, F. K. R., De Lima, H. V., Dos Santos, M. A. S., Dos Santos, P. C., \& Lopes, M. L. B. (2019). Socio-economics of Acai Production in Rural Communities in the Brazilian Amazon: A Case Study in the Municipality of Igarapé-Miri, State of Pará. Journal of Agricultural Science, 11(5), 215. https://doi.org/10.5539/jas.v11n5p215

Fajardo, J. D. V., Souza, L. A. G. De, \& Alfaia, S. S. (2009). Características químicas de solos de várzeas sob diferentes sistemas de uso da terra, na calha dos rios Baixo Solimões e Médio Amazonas. Acta Amazonica, 39, 731-740. https://doi.org/10.1590/S0044-59672009000400001

Farias Neto, J. T., Resende, M. D. V., \& Oliveira, M. S. P. (2011). Seleção simultânea em progênies de açaizeiro irrigado para produção e eso do fruto. Revista Brasileira de Fruticultura, 33(1), 532-539. https://doi.org/10.1590/S0100-29452011000200025

Forster, S., Lena, K. S., Eva, K., Erwin, G., Jörg, K., Dirk, B., ... Dirk, B. (2019). Wounding-Induced Stomatal Closure Requires Jasmonate-Mediated Activation of GORK K+ Channels by a Ca ${ }^{2+}$ Sensor-Kinase CBL1-CIPK5 Complex. Developmental Cell, 48, 87-99. https://doi.org/10.1016/j.devcel.2018.11.014

Freitas, L. Da J., Santos Dos, E. S., \& Oliveira, De A. F. (2015). Avaliação de atributos químicos do solo em ambientes de terra firme e várzea no município de Santana, Amapá. Biota Amazônia, 5(4), $27-33$. https://doi.org/10.18561/2179-5746/biotaamazonia.v5n4p27-33

Freitas, M. A. B., Vieira, I. C. G., Albernaz, A. L. K. M., Magalhães, J. L. L., \& Lees, A. C. (2015). Floristic impoverishment of Amazonian floodplain forests managed for açaí fruit production. Forest Ecology and Management, 351, 20-27. https://doi.org/10.1016/j.foreco.2015.05.008

Gee, G. W., \& Bauder, J. W. (1986). Particicle-size Analysis. In C. A. Klute (Ed.), Methods of soil Analysis (2nd ed., pp. 383-411). Medison, Wisconsin. https://doi.org/10.2136/sssabookser5.1.2ed.c15

Geoffrey, H. B., \& Hall, D. J. (1965). ISODATA, a novel method of data analysis and patern classification (Technical Report April 1965). Stanford Research Institute Menlo Park, California.

Gomes, J. C. (2001). Fotointerpretação I. Guaratinguetá: Centro de Instrução e Adaptação da Aeronáutica.

Gonçalves De, L. D., \& Brasil, D. D. S. B. (2016). Problemas ambientais e sustentabilidade nas várzeas da Amazônia Tocantina: Um estudo no Projeto de Assentamento Agroextrativista São João Batista II, Abaetetuba, Estado do Pará, Brasil. Revista Pan-Amazônica de Saúde, 7(4), 11-11. https://doi.org/ $10.5123 / \mathrm{S} 2176-62232016000400011$

Guedes, A. C. L., Ferreira, J. A., Júnio, N. J. M., \& Guedes, M. C. (2018). Coletores para quantificar a entrada de sedimentos em florestas de várzea Estuarina. Embrapa Amapá-Boletim De Pesquisa E Desenvolvimento (INFOTECA-E).

Homma, A. K. (2014). Extrativismo vegetal ou plantio: Qual a opção para a Amazônia? In A. K. O. Homma (Ed.), Extrativismo vegetal na Amazônia: História, ecologia, economia e domesticação. Brasília, DF: Embrapa.

Homma, A. K. O., Nogueira, O. L., De Menezes, A. J. E. A., De Carvalho, J. E. U., Nicoli, C. M. L., \& De Matos, G. B. (2006). Açaí: Novos desafios e tendências. Amaz. Ciência Desenvol, 1, 7-23.

IBGE (Instituto Brasileiro de Geografia e Estatística). (2012). Manual técnico da vegetação brasileira.

IBGE (Instituto Brasileiro de Geografia e Estatística). (2019). Censo do municipio de garapé-mirim-PA. Retrieved October 21, 2020, from https://cidades.ibge.gov.br/brasil/pa/igarape-miri/panorama 
Jardim, M. A. G., Amaral, D. D., Santos, G. C. D., Medeiros, T. D. S., Silva, C. A. D., Francez, D. D. C., \& Costa Neto, S. V. (2004). Análise florística e estrutural para avaliação da fragmentação nas florestas de várzea do estuário amazônico. Museu Paraense Emilio Goeldi.

Lima, A. M. T., Ataídes, A. G. De., Souza, E. P. B. De., Seibert, C. S., \& Mucari, T. (2018). Área de (des) proteção ambiental Serra do Lajedo-TO: Degradação ambiental identificada por análise de cobertura vegetal e crimes registrados no período de 2001 a. Gaia Scientia, 12(1), 259-272. https://doi.org/10.22478/ ufpb.1981-1268.2018v12n1.32877

Lôbo, D., Leão, T., Melo, F. P. L., Santos, A. M. M., \& Tabarelli, M. (2011). Forest fragmentation drives Atlantic forest of northeastern Brazil to biotic homogenization. Divers. Distrib., 17, 287-296. https://doi.org/ 10.1111/j.1472-4642.2010.00739.x

Loch, C. (1993). Noções básicas para interpretação de imagens aéreas, bem como algumas de suas aplicações nos campos profissionais (3rd ed., p. 120). Florianópolis, UFSC.

Lopes, E. L. N., Fernandes, A. R., Grimaldi, C., Ruivo, M. D. L. P., Rodrigues, T. E., \& Sarrazin, M. (2006). Características químicas de um Gleissolo sob diferentes sistemas de uso, nas margens do rio Guamá, Belém, Pará. Bol. Mus. Para. Emílio Goeldi. Ciências Naturais. https://doi.org/10.5123/S1981-811420060 00100009

Lopes, M. R., Nogueira, A. V. M., Lopes, B. M., Xavier, B. H. M., Coelho, N. C. O., Mata, E. L. O., \& Lopes, E. L. N. (2019). Caracterização físico-química de gleissolo de várzea da região do baixoTocantins, PA. Revista Craibeiras de Agroecologia, 4(SP), e8953.

Matsukuma, C. K. (2002). Análise comparativa de algoritmos de classificação digital não-supervisionada, no mapeamento do uso e cobertura do solo (Tese de Doutorado, Universidade de São Paulo, Brazil).

Meneses, P. R., \& Almeida, De T. (2012). Introdução ao processamento de imagens de sensoriamento remoto UNB, Brasilia (p. 276).

Morariu, O., Burescu, F., Herbei, P. E. M. V., \& Chis, P. C. (2018). Agricultural land cover classification using Rapideye satellite imagery. Journal of Young Scientist, 6.

Moreira, M. A. (2003). Fundamentos do sensoriamento remoto e metodologias de aplicação. 2ed. Viçosa: UFV.

Nogueira, O. L. (1997). Regeneração, manejo e exploração de açaizais nativos de várzea do estuário amazônico (Tese Apresentada ao Curso de Pós-graduação em Ciências Biológicas do Centro de Ciências Biológicas da Universidade Federal do Pará, do Museu Paraense Emílio Goeldi e da Empresa Brasileira de Pesquisa Agropecuária).

Olofsson, P., Foody, G. M., Herold, M., Stehman, S. V., Woodcock, C. E., \& Wulder, M. A. (2014). Good practices for estimating area and assessing accuracy of land change. Remote Sensing of Environment, 148, 42-57. https://doi.org/10.1016/j.rse.2014.02.015

Rodrigues, T. E., Silva, J. M. L. Da, Silva, B. N. R. Da, Valente, M. A., Gama, J. R. N. F., Santos, E. S. Dos, ... Ponte, F. C. Da. (2005). Caracterização e classificação dos solos do município de Tailândia, estado do Pará (p. 55). Belém, PA: Embrapa Amazônia Oriental.

Rodríguez-Echeverry, J., Fuentes, R., Leiton, M., \& Jaque, E. (2018). Changing Landscapes Forest: Implications for its Conservation. Environment and Natural Resources Research, 8(3), 44. https://doi.org/10.5539/ enrr.v8n3p44

Salviano, A. A. C., Vieira, S. R., \& Sparovek, G. (1998). Variabilidade espacial de atributos de solo e de Crotalaria juncea L. em área severamente erodida. Revista Brasileira de Ciência do Solo, 22(1), 115-122. https://doi.org/10.1590/s0100-06831998000100016

Santos Júnior, H. B., Batista Júnior, W. F., \& Jardim, M. A. G. (2015). Formas tradicionais no manejo de palmeiras como alternativas de conservação ambiental. $9^{\circ}$ Congresso Brasileiro de Agroecologia, Belém. Cadernos de Agroecologia, 10, 54-59.

Silva, A., Brito, A., Mendes, F., Chagas, H., Silva, T., \& Coelho, R. (2018). Os ribeirinhos e os Sistemas agroflorestais agroecológicos na ilha Mamangal, Igarapé-Miri-Pará. Cadernos de Agroecologia, 13(1).

Swain, P. H., \& Davis, S. M. (1978). Remote Sensing: The Quantitative Approach (p. 375). McGraw Hill Book Company, New York, NY. 
Tagore, M. D. P. B., Do Canto, O., \& Sobrinho, M. V. (2018). Políticas públicas e riscos ambientais em áreas de várzea na Amazônia: O caso do PRONAF para produção do açaí. Desenvolvimento e Meio Ambiente, 45. https://doi.org/10.5380/dma.v45i0.51585

Teixeira, P. C., Donagemma, G. K., Fontana, A., \& Teixeira, W. G. (2017). Manual de Métodos de Análise de Solos (3rd ed., p. 573). Revista e Ampliada, Brasília: Embrapa.

Temba, P. (2000). Fundamentos da fotogrametria. Belo Horizonte: Departamento de Cartografia, Universidade Federal de Minas Gerais.

Tregidgo, D., Campbell, A. J., Rivero, S., Freitas, M. A. B., \& Almeida, O. (2020). Vulnerability of the Açaí Palm to Climate Change. Human Ecology, 48(4), 505-514. https://doi.org/10.1007/s10745-020-00172-2

Van Breemen, N., \& Buurman, P. (2002). Hydromorphic soils. Soil Formation (2nd ed.). New York: Kluwer Academic Publishers. https://doi.org/10.1007/0-306-48163-4

Vasconcelos, M. A. D., Oliveira, M. A. F. D., Guimarães, D. F. D. S., \& Pereira, H. D. S. (2016). As transformações sazonais da paisagem na Ilha do Careiro e suas consequências socioambientais. Revista Amazônica de Ensino de Ciências.

Veloso, H. P., Rangel Filho, A. L. R., \& Lima, J. C. A. (1991). Classificação da vegetação brasileira, adaptada a um sistema universal. IBGE, Rio de Janeiro.

Verma, A. K., Garg, P. K., \& Prasad, K. H. (2017). Sugarcane crop identification from LISS IV data using ISODATA, MLC, and indices based decision tree approach. Arabian Journal of Geosciences, $10(1), 16$. https://doi.org/10.1007/s12517-016-2815-X

Walkley, A., \& Black, I. A. (1934). An examination of the degtyareff method for determining soil organic matter and a proposed modification of the cromic acid titration method. Soil Science, 37, 29-38. https://doi.org/10.1097/00010694-193401000-00003

Wang, Y., Chen, F., Zhang, M., Chen, S., Tan, X., Liu, M., \& Hu, Z. (2018). The effects of the reverse seasonal flooding on soil texture within the hydro-fluctuation belt in the Three Gorges reservoir, China. Journal of Soils and Sediments, 18(1), 109-115. https://doi.org/10.1007/s11368-017-1725-1

\section{Copyrights}

Copyright for this article is retained by the author(s), with first publication rights granted to the journal.

This is an open-access article distributed under the terms and conditions of the Creative Commons Attribution license (http://creativecommons.org/licenses/by/4.0/). 